International Journal of Agriculture, Environment and Bioresearch

Vol. 4, No. 06; 2019

ISSN: $2456-8643$

\title{
INFLUENCE OF WATER LEVELS ON THE YIELD PARAMETERS OF COCOA IN THE FOREST SAVANNAH-TRANSITION ZONE OF GHANA
}

\author{
Kotei Richard \\ Department of Agriculture Engineering and Mechanization, College of Agriculture Education,University of \\ Education, Winneba, P.O. Box 40, Mampong-Ashanti, Ghana. \\ http://doi.org/10.35410/IJAEB.2019.4495
}

\begin{abstract}
The study was carried out inthe Forest-Savanah Transition zone of Ghana to determine the influence of different water quantities on yield parameters of 13 years old 'Series II', a biparental hybrid of Amelonado and Trinitarioscocoa, (Theobroma cacao L) from December to August. The randomized complete block design with four treatments and four replications was used. The treatments were 0 liters (control) (T0), 20 liters (T1), 30 liters (T2) and 40 liters (T3) of water applied per plant per day. The parameters studied were: number of cocoa pods per plant, weight of fresh cocoa pods, number of beans per pod and weight of hundred (100) dry beans. The weight of dried beans and weight of fresh pod were significantly affected by the water levels. The results revealed that 30 liters of water (T2) when applied during the period of drought gave maximum value in all the performance parameters. It is recommended that cocoa farmers with irrigation facilities in the Forest-Savannah Transition zone can apply 30 liters of water daily during the dry season and to supplement rainfall to ensure continuous production of cocoa throughout the year.
\end{abstract}

Keywords: Irrigation, Drought length, Crop water requirement, Yield parameters.

\section{INTRODUCTION}

Cocoa (Theobroma cacao L.) is by far the most important crop in Ghana in the Humid Tropics. It is a major source of income to over 800,000 farmers and many others engaged in trade; transportation and processing of cocoa [1]. Cocoa contributes, globally, to the livelihoods of 4050 million people [2]. The share of the crop alone in Ghana's GDP is $8.2 \%$ and about $23 \%$ of foreign exchange earnings [3]; [4]. However, low yields due, mainly, to climate change have contributed to the decline in production of the crop from 1,025,000 metric tons in 2011/12 [5] to about 700,000 metric tons in 2014/2015 in Ghana [6].

One of the limiting factors affecting the yield of cocoa is availability and distribution of rain fall. Studies have shown that the yield of cocoa is strongly related to drought length [7]. Using a simulation model, [8] demonstrated that annual mean radiation and rainfall during the dry season explained $70 \%$ of the variations in annual seed yields of cocoa obtained from 30 production zones along the tropical areas of the world. Also, [9] as cited in [7] posits the positive correlations between yield of cocoa and rainfall during months that precede harvest which fall within the study period. 
In Ghana, [10] have reported on the high sensitivity of cocoa to changes in length and intensity of sunshine, rainfall, soil condition and temperature with the resultant effect on evapotranspiration (the drying ability of the atmosphere). Again, there is evidence of a decline in the annual rainfall in the agro-ecological areas where cocoa is concentrated in Ghana [11]. According to Carr and Lockwood (2011), there is a paucity of reliable published data on yield and other benefits that could result from well-managed irrigation of cocoa in different climatic zones.

This study was to determine the influence of different irrigation water quantities on yield parameters of a 13 years old 'Series II', a bi-parental hybrid of Amelonado and Trinitarioscocoa, in the Forest-Savannah Transition zone of Ghana under increased temperature, wind velocity and actual evapotranspiration (ETa) [13].

\section{MATERIALS AND METHODS}

\subsection{Description of the Study Site}

The study was carried out on a 13 years old cocoa farm at the College of Agriculture Education, University of Education, Winneba, in the Ashanti Region. The area is located $62 \mathrm{Km}$ North of Kumasi on the Kumasi-Ejura-Yeji trunk road and lies within longitudes $1.30^{\circ}$ and $1.35^{\circ}$ West and latitudes $6.35^{\circ}$ and $6.40^{\circ}$ North. The annual rainfall ranges between $1270 \mathrm{~mm}$ and 1524 $\mathrm{mm}$ with the mean monthly being $91.2 \mathrm{~mm}$. The rainfall pattern in the area is bimodal [14].

\subsection{Experimental Design and Procedure}

The experimental design was randomized complete block design (RCBD) with four treatments and four replications. The treatments consisted of water application levels at 0 liters $\left(\mathrm{T}_{0}\right)$ (control), 20 liters $\left(\mathrm{T}_{1}\right), 30$ liters $\left(\mathrm{T}_{2}\right)$ and 40 liters per day $\left(\mathrm{T}_{3}\right)$. The water quantities were delivered by drip irrigation system at $50 \%$ incremental difference between treatments due to increased rate of evapotranspiration reported by[13] in the study area. Plants used were randomly selected, of the same variety and at the same maturity level. Data collected included average number of pods per plant, average weight of fresh pod, average number of beans per pod and average weight of 100 dry beans. The experiment ran for nine months (December - July). The treatments and intervals were taken from [15], who published that water stress symptoms in cocoa were observed at drip irrigation water quantities between 15 and 20 liters/day/plant while optimal responses and yields were achieved between 25 and 30 litres/day/plant.

\subsection{Treatments}

The treatments employed were:

$\mathrm{T}_{0}-$ No irrigation (control)

$\mathrm{T}_{1}-20$ litres per day

$\mathrm{T}_{2}-30$ litres per day

$\mathrm{T}_{3}-40$ litres per day

All fruits on the trees before the application of the treatments were removed. All approved pest and disease control, preventive and cultural measures were applied as planned by the university farm.

\subsection{Prevailing Climate Variables}


[13] posited that the mean annual decadal rainfall days in the last decade (2000-2009) have dropped by 5.30\% from 1990-1999 decade. This can significantly affect the antecedent soil moisture and increase its variation during the period.

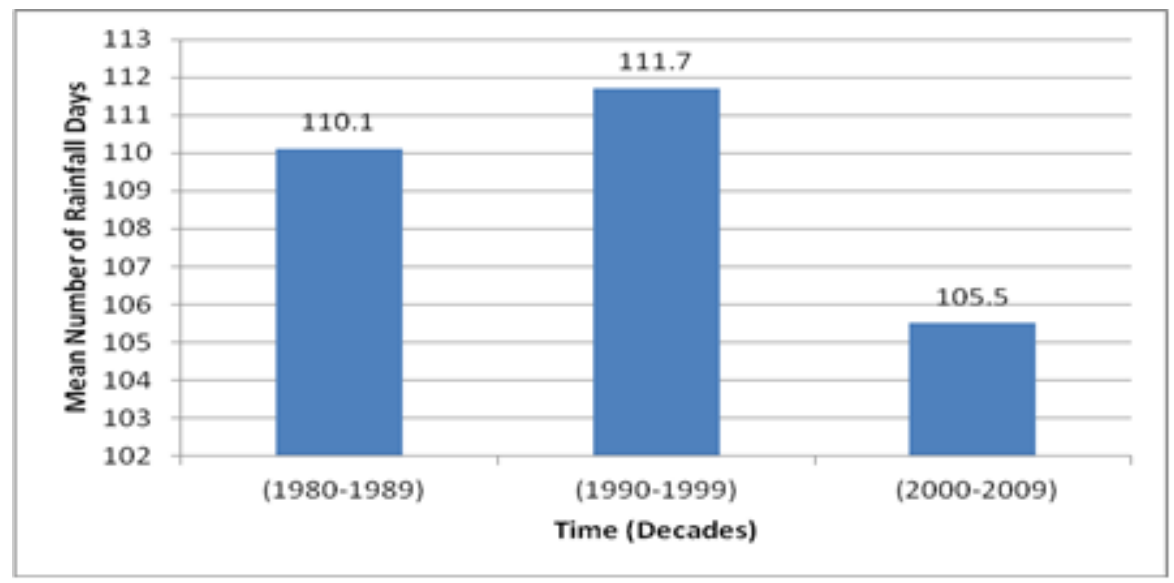

Figure 1: Mean Number of Rainfall Days (1980-2009) [13]

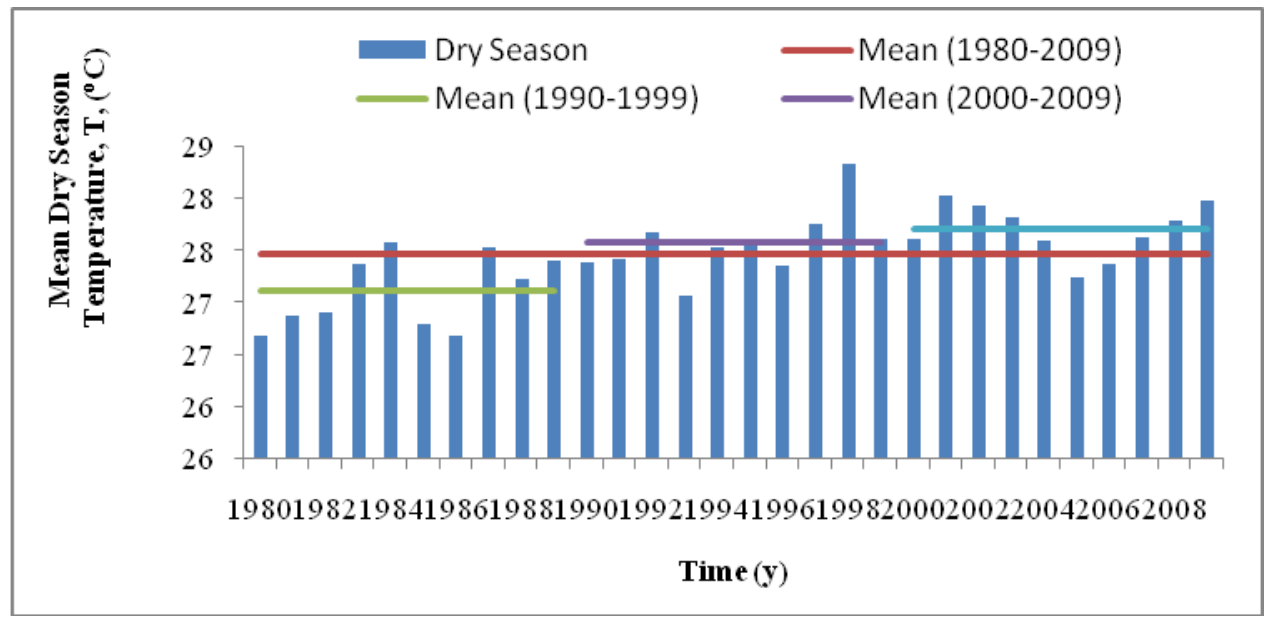

Figure 2: Changes in Mean Decadal Dry Season Temperatures (1980-2009) [13] 
Table 2.2: Intra-annual Temperatures $\left({ }^{\circ} \mathrm{C}\right)(1980-2009)$

\begin{tabular}{|llllll|}
\hline & Mean & Max & Min & Stdev & $\begin{array}{l}\text { CV } \\
\text { (\%) }\end{array}$ \\
Jan & 31.59 & 33.40 & 30.50 & 0.77 & 2.43 \\
Feb & 32.77 & 33.80 & 31.20 & 0.69 & 2.10 \\
Mar & 34.34 & $\mathbf{3 6 . 1 0}$ & 32.60 & 0.92 & 2.67 \\
Apr & 33.68 & 35.70 & 32.00 & 0.96 & 2.85 \\
May & 32.63 & 34.10 & 31.50 & 0.54 & 1.67 \\
Jun & 31.78 & 32.50 & 30.70 & 0.48 & 1.50 \\
Jul & 30.11 & 31.00 & 29.20 & 0.53 & 1.75 \\
Aug & 28.56 & 29.50 & 27.10 & 0.68 & 2.38 \\
& $\mathbf{2 8 . 1 9}$ & 29.20 & 26.70 & 0.56 & 1.98 \\
\hline
\end{tabular}

\section{Source: Koteiet al. (2016)}

The decadal dry season temperature in the study area has increased in the last decade (Figure 2). This has accelerated the water cycle in the study area. And with the decrease in the rainfall days, the crop will experience frequent and long periods of water stress which, if it occurs at the production times, will significantly, and negatively, affect flowering, fruit set and pod development. The study was conducted in a temperature range of $7.91^{\circ} \mathrm{C}$ (Maximum $36.10^{\circ} \mathrm{C}$ and Minimum $-28.19^{\circ} \mathrm{C}$ ). Such a range is capable of, significantly, influencing the soil water regime and the physiological processes of the crop finally on the yield parameters.

\subsection{Data Analysis}

The data were statistically analysed using [16] for analysis of variance. The least significance difference (LSD) at 5\% was used to separate the means.

\section{RESULTS}

\subsection{Effects of Irrigation Water Quantities on Number of Pods Per Plant}

The lowest mean number of pods per plant was recorded by the $\mathrm{T}_{0}(11)$ during the period under study. Trees receiving 30 litres per day $\left(\mathrm{T}_{2}\right)$ recorded the highest influence in the number of pods per plant with a mean value of 41 , showing 30 pods $(273.00 \%)$ higher than the control $\left(\mathrm{T}_{0}\right), 2$ pods $(5.10 \%)$ higher over trees that received 40 litres per day $\left(\mathrm{T}_{3}\right)$ and 17 pods $(70.83 .00 \%)$ higher over trees that received 20 litres per day $\left(\mathrm{T}_{1}\right)$. There was no significant difference between the $30 \mathrm{~L}$ and $40 \mathrm{~L}$ per plant per day treatments $(\mathrm{p}<0.05)($ Table 1$)$. 
Table 2.1: Mean yield of cocoa at different water levels

\begin{tabular}{|l|lr|l|l|l|}
\hline Treatment & $\begin{array}{l}\text { No. } \\
\text { pods per } \\
\text { plant }\end{array}$ & $\begin{array}{l}\text { Average } \\
\text { Weight of } \\
\text { fresh pod } \\
\text { per plant } \mathbf{( g )}\end{array}$ & $\begin{array}{l}\text { Number of } \\
\text { beans per } \\
\text { pod }\end{array}$ & $\begin{array}{l}\text { Weight of } \\
\text { 100 beans } \\
\text { per plant } \\
\text { (g) }\end{array}$ \\
\hline $\mathrm{T}_{0}$ & 11.00 & 348.01 & 26 & 89.40 \\
\hline $\mathrm{T}_{1}$ & 24.00 & 439.10 & 36 & 122.30 \\
\hline $\mathrm{T}_{2}$ & 41.00 & 469.00 & 47 & 130.70 \\
\hline $\mathrm{T}_{3}$ & 39.00 & 377.02 & 32 & 109.70 \\
\hline Mean & 28.80 & 407.00 & 35.25 & 113.0 \\
\hline $\mathrm{CV}(\%)$ & 26.60 & 64.70 & 7.8 & 5.80 \\
\hline LSD $(<0.05)$ & 8.63 & 14.10 & 4.41 & 7.36 \\
\hline
\end{tabular}

\subsection{Effect on Weight of 100 Beans}

The results indicated significant difference $(\mathrm{P}<0.05)$ among the treatments with respect to weight of 100 dry beans (Table 2.1). Again, $\mathrm{T}_{2}$ recorded the highest weight of $130.7 \mathrm{~g}(1.307 \mathrm{~g}$ per bean); an improvement of $46.20 \%(41.30 \mathrm{~g}), 19.14 \%(21.0 \mathrm{~g})$ and $6.87 \%(8.40 \mathrm{~g})$ over the control $\left(T_{0}\right), T_{3}$ and $T_{1}$ respectively. This indicates that, to attain optimum weight of dry beans when cocoa plants are not rain fed or during the dry season and for supplementary irrigation 30 liters of water could be applied per day per plant under the prevailing climate conditions. The lowest weight of beans recorded in $\mathrm{T}_{3}$, even though it received the highest water quantity, was, again, due to the growth suppression of trees on constantly close to saturation soil [16] for nine (9) months. It could be concluded that the 30L of water provided adequate water for protein and carbohydrate production for bean growth and development resulting in higher weight. The results also revealed that beans harvested in the dry seasons, without irrigation, was giving farmers lower income since beans harvested during that period were smaller both in size and weight than those harvested in the rainy season and under supplemented irrigation.

\subsection{Effect on the Weight of Fresh Pod (g)}

In the weight of fresh pod, the 30 liters per day water delivery $\left(\mathrm{T}_{2}\right)$, again, produced the highest weight of fresh pod $(469.00 \mathrm{~g}$ ) (Table 2.1) indicating a significant increase of $121.0 \mathrm{~g}$ $(34.78 \%)$ over the control $\left(\mathrm{T}_{0}\right), 30.0 \mathrm{~g}(6.83 \%)$ over $\mathrm{T}_{1}(20$ liters per plant per day)and $92.0 \mathrm{~g}$ $(24.40 \%)$ over the 40 liters per plant per day $\left(\mathrm{T}_{3}\right)$. There was significant difference between all the weight values $(\mathrm{p}<0.05)$ (Table 2.1). Whether this will reflect in the bean weight, we have to look at the weight of dry beans from these heavy pods.

\subsection{Number of Beans Per Pod}


The results revealed the quantities of water had significant influence on the number of beans per pod. The most significant increase was recorded by $\mathrm{T}_{2}$ (47) (30 $\mathrm{L}$ of water per tree per day) indicating an increase of 21 beans $(80.8 \%)$ over $\mathrm{T}_{0}, 11$ beans $(30.6 \%)$ over $\mathrm{T}_{1}, 15$ beans $(46.9 \%)$ over $\mathrm{T}_{3}$. This observation agrees with earlier reports that flowering intensity is greatest between April and June (major season) [18] where the rainfall sustains optimum soil moisture contents. The increase in rainfall from May promoted flowering intensity than that observed in January where the minimum, mean and maximum temperatures were higher. [9] also observed that flowering intensity is strongly affected by rainfall and temperature. Warm climate and increased rainfall (May) promoted flushing and flower initiation in T. cacao. Also, in cocoa, photosynthetic rates decrease once optimum temperatures are exceeded (January), affecting vegetative and reproductive growth and development [7].

\section{DISCUSSION}

\subsection{Effects of Irrigation Water Quantities on Number of Pods Per Plant}

According to [12] and [16], cocoa plants subjected to water stress experience poor efflorescence production, fruit setting and pod development. This is due to suppression of reproductive growth when crop is water stressed. Rainfall below $1200 \mathrm{~mm} /$ year lowers cocoa productivity and in most cases damages the plant [9]. This means that, during the dry seasons when a farmer desires to provide water through irrigation to mature Amelonado cocoa plants in the Forest-Savannah Transition Zone, 30 liters per day could make for optimum yield.

\subsection{Effect on Weight of 100 Beans}

The weight of the cocoa bean harvested is very important since purchases are made in weights and not size. The results in section 3.1 indicates that, to attain economic weight of dry beans when cocoa plants are irrigated completely, during the dry season, or under supplementary irrigation, 30 liters of water could be applied per day per plant under the prevailing climate conditions. The lowest weight of beans recorded in $\mathrm{T}_{3}$, even though it received the highest water quantity ( $40 \mathrm{~L}$ per plant per day). This was due to the growth suppression of trees on soils constantly close to saturation [16] for nine (9) months continuously. This is supported by [9] who published that when rainfall exceeds $2,500 \mathrm{~mm} /$ year to $3,000 \mathrm{~mm} / \mathrm{year}$, cocoa yields are reduced due to water-logged or constantly saturated soil for part of the year. It could be concluded that the $30 \mathrm{~L}$ of water was optimum to provided adequate water for protein and carbohydrate production for bean growth and development resulting in higher weight. The results also revealed that beans harvested in the dry seasons, without irrigation, was giving farmers lower income since beans harvested during that period were smaller both in size and weight than those harvested in the rainy season and under supplemented irrigation.

\section{CONCLUSION}

The study shows that the application of water to cocoa in supplementary irrigation or during the dry season in the Forest-Savannah Transition zone had significant influence on its yield and productivity. There was significant increase in the number of pods per plant and ultimately the weight and size of cocoa beans with 30 liters of water per tree per day under drip irrigation when all soil requirements are met.

\section{RECOMMENDATION}


Considering the evidence of a decline in the annual rainfall and its distribution coupled with atmospheric warming in the agro-ecological area where cocoa is concentrated in Ghana [11], every effort should be made to collect and use on farm climate data to develop appropriate water management models and strategies, where water is available, for cocoa farmers to adapt to and operate within the prevailing climatic conditions to sustain productivity of cocoa throughout the year to improve and sustain their economic life.

\section{REFERENCES}

[1] World Bank (2013). Ghana - Cocoa supply chain risk assessment. Washington DC ; World Bank.

[2] World Cocoa Foundation (2010). http://www.worldcocoafoundation.org/learn-aboutcocoa/cocoa-facts-andfigures.html.

[3] Global Agricultural Information Network (GAIN) (2012). Cocoa Annual Report.

[4] ICO (International Cocoa Organization) (2012). The World Cocoa Economy: Past and Present.

[5] Ecobank (2014). Middle Africa Briefing Note -Soft Commodities- Cocoa- Ghana: Cocoa sector is facing new challenges.

[6] GBN (Ghana Business News) (2015). The sad story of Ghana's cocoa industry and the way forward. Available online at https://www.ghanabusinessnews.com/2015/06/22/the-sad-story-ofghanas-cocoa-industry-and-the-way-forward .Retrieved on November 20, 2016.

[7] Almeida, A. A. F. de and Valle, R. R. (2008). Ecophysiology of the cacao tree.Brazilian Journal of Plant Physiology 19:425-448.

[8] Zuidema, P.A., Leffelaar, P.A., Gerritsma, W., Mommer, L. and Anten, N. P. R. (2005). A physiological production model for cocoa (Theobroma cacao): model presentation, validation and application. Agric. Syst. 84:195-225.

[9] Alvim, P. de T. (1977). Cocoa. In Ecophysiology of tropical crops, (Alvim, P. de T. and Kozlowski, T.T., eds.), London: Academic Press. p. 279-313.

[10] Anim-Kwapong, G. J. and Frimpong, E. B. (2006). Vulnerability of agriculture to climate change - impact of climate change on cocoa production.In Report on Vulnerability and Adaptation Assessment under the Netherlands Climate Change Studies Assistance Programme Phase 2.Cocoa Research Institute of Ghana.

[11] Owusu, K. and Waylen, P. (2009). Trends in spatial-temporal variability in annual rainfall in Ghana (1951-2000). Weather, 64:115-120.

[12] Carr, M. K.V. and Lockwoods, G. (2011). The water relations and irrigation Requirements of cocoa (theobroma cacao 1.): a review. Expl Agric., 47 (4), pp. 653-676.

[13] Kotei, R., Kyei-Baffour, N., Atakora, E. T. and Monney, I. (2016). Influence of Change In Climate And Urban Characteristics On Hydraulic Designs And Drainage System In MampongAshanti, Ghana. ARPN Journal of Earth Sciences.5(2), pp. 90 -99.

[14] Meteorological Service Agency (2002). Annual report.

[15] Balisimah, D. and Apshara, S. E. (2007). CPCRI: Cocoa breeding and physiology in India: Gro-Cocoa. Issue 11.Pp.5-7.

[16] Genstat. (2008). Genstat for Windows, Release 11.1, Eleventh Edition. VSN international limited., Oxford 
International Journal of Agriculture, Environment and Bioresearch

Vol. 4, No. 06; 2019

ISSN: $2456-8643$

[17] Sena-Gomes, A.R. and Kozlowski, T. T. (1988). Physiological and growth responses to flooding of seedlings of Heveabrasiliensis. Biotropica 20: 286-293.

[18] Gordon, J. (1976). Cocoa: Its nature, habitat and cultivation. In: Cocoa Production, Economic and Botanical Perspectives .Springer Publishers Simmons, J. (Ed.).NewYork.Pp 329. 